\title{
UNIVERSITY COLLEGE, IBADAN
}

\section{FORMAL OPENING}

$\mathrm{O}$ November 17, Marshal of the Royal Air Force Lord Tedder, Chancellor of the University of Cambridge, formally opened the buildings of what in a few years time will be the University of Nigeria. This was the fourth anniversary of the ceremony when the then Secretary of Stato for the Colonies, Mr. Arthur Creech Jones, cut the first sod and inaugurated the building programme ; the Soil Science Laboratory of the Department of Agriculture appropriately stands on the spot. Less than six years ago a commission appointed by the Inter-University Council for Higher Education in the Colonies, under the chairmanship of Sir William Hamilton Fyfe, selected the site, which was then a tract of unsurveyed and almost impenetrable bush.

The capital cost of the new buildings has been provided by a grant from the British Exchequer under the Colonial Development and Welfare Act. The sum of $£ 1,500,000$ was set aside in 1947 , and on November 17 Sir Christopher Cox, educational adviser at the Colonial Office, announced, on behalf of the Secretary of State, that a further $£ 200,000$ had been added, to offset increased prices and to allow the whole of the first phase of the scheme to be completed. The whole of the recurrent costs of the College, which now amount to about $£ 400,000$ per annum, come from Nigerian sources, either as a direct subvention from the Government or as interest from endowments from the same source or from the marketing boards (for example, the Cocoa Marketing Board has endowed the School of Agriculture to the extent of $£ 1,000,000$ ).

The site of nearly 3,000 acres was acquired for the College by the Nigerian Government and lies some three miles north of Ibadan. Ibadan is the largest town in tropical Africa, with an estimated population of half a million inhabitants, mostly Yoruba, but with substantial numbers of settlers from other parts of Nigeria, and a few hundred European, Syrian, Indian and other expatriates.

The site, as well as containing the main academic buildings, houses more than a hundred members of the academic staff, and several hundred junior employees. The greater part of the 3,000 acres will, however, be developed as experimental farms by the Department of Agriculture.

The buildings, designed by $\mathbf{M r}$. Maxwell Fry and Miss Jane Drew, comprise residential accommodation for nearly six hundred student in halls of residence and teaching blocks for the departments in the Faculty of Arts, including a theatre, library, administration building and an assembly hall; this last is a gift from the United Africa Company, and is to be called
Trenchard Hall, after Lord Trenchard, chairman of the Company, who during 1903-10 saw service with the Army in Nigeria.

There are at this stage four halls of residence, in each of which the plan follows the general recommendations of the committee set up by the vicechancellors and principals of universities in Britain. Each undergraduate has a separate study-bedroom, and there are a communal dining hall and recreation rooms in each hall of about 150 students. The buildings have been planned for tropical conditions, and although they are built around courtyards, most of the residential blocks run east and west to avoid direct sun shining into the rooms. Each room has through ventilation, and each study-bedroom a private veranda.

The laboratories, for the Departments of Chemistry, Physies, Botany and Zoology in the Faculty of Science, for Agriculture, for Anatomy, Physiology and Pharmacology in the Faculty of Medicine, have been planned for construction with the maximum economy, and so as to be easily adapted and converted to meet changing needs. These buildings have been designed by Mr. J. Hoskins, of the College staff, collaborating where necessary with the architects to ensure that the façade conforms with the general layout plan. These laboratories are of one story only (this is much cheaper to construct under Nigerian conditions than loftier buildings), and they are planned to be able to house a much larger number of students and of staff than will immediately be necessary. Thus the Departments both of Chemistry and of Physics have each about 18,000 sq. ft. of laboratory space.

The buildings now constructed are intended to house the College in the first phase of its development ; but the site has been planned so that a great expansion is possible. More halls of residence are likely to be the first necessity, and sites for at least six more are scheduled. The teaching departments can be easily extended to take several thousand students,

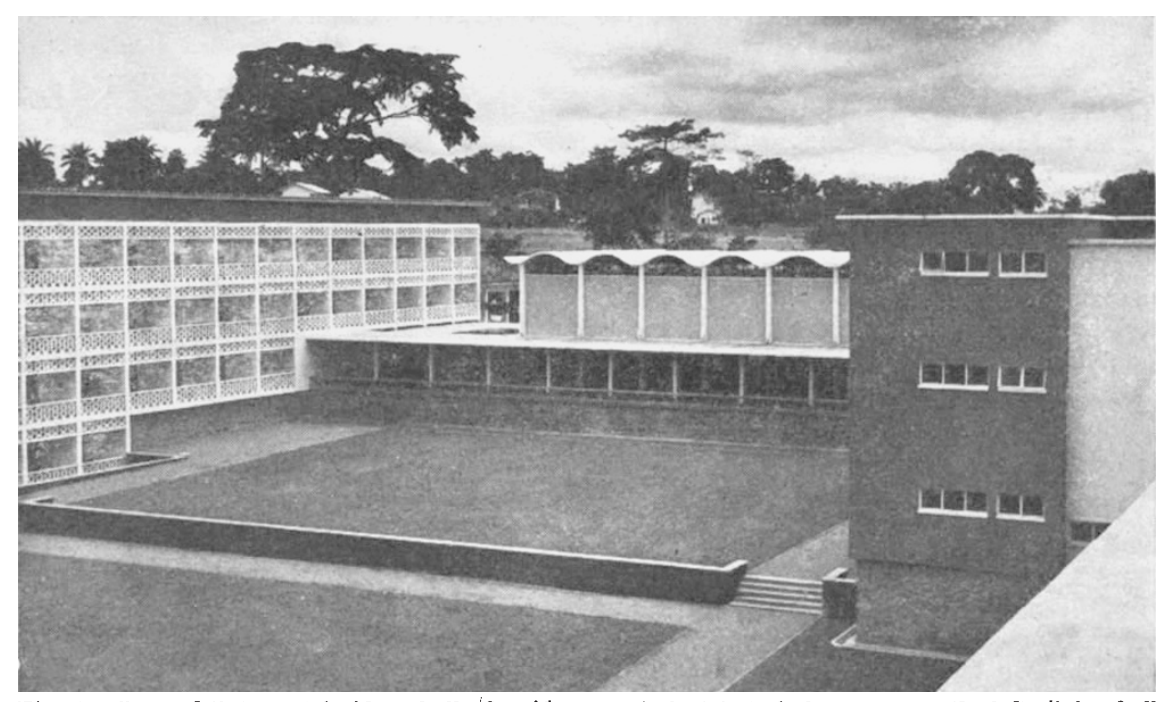

Fig. 1. Part of the court inside a hall of residence; students' study-bedrooms on the left, dining hall 


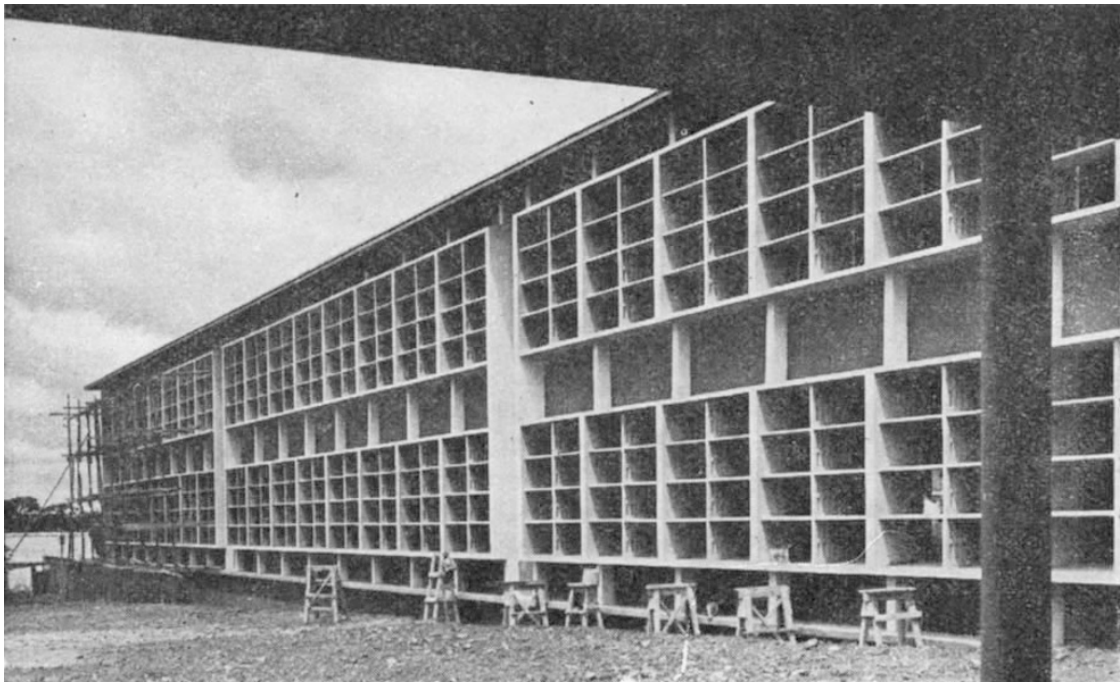

Fig. 2. North wing of the arts building, containing Departments of Geography, Mathematics and notwithstanding the obvious demand for wellqualified scientists and technicians, arts subjects are by no means neglected.

Academic work in the tropics often suffers from the lack of library facilities. The library at Ibadan already contains more than 70,000 volumes, and receives about a thousand current periodicals. The new building will take, without extension, more than a quarter of a million volumes. Microfilms are extensively used, being frequently flown out from Europe for the urgent use of readers, and the library can make its own microfilms and photostat

though those at present responsible for planning the College think that when the undergraduate community reaches about 2,500 a start should be made with a second Nigerian university in another part of the territory.

The College has already been working for more than four years in temporary buildings in a converted military hospital. The preclinical and agricultural students have now moved into their permanent quarters; but the Faculties of Arts and Science will not be able to move for some months. There are at present in residence in Ibadan nearly 400 undergraduates, and an academic staff of more than a hundred.

Ibadan students work for degrees of the University of London. The College is in a "special relationship" with the University ; this means that, while academic standards are guaranteed, there is some latitude in adapting the syllabus to meet local needs. Thus in the biological sciences, geography and history, for example, special courses have been evolved. The preparation of these syllabuses, which will develop as the appropriate research work into African problems progresses, gives useful experience which will be of value when the College becomes an independent university.

The whole course leading to general or honours degrees in a wide range of arts and science subjects, and in agriculture, can be completed in Ibadan. In medicine, teaching at present only extends to the end of the preclinical course ; for clinical studies, students proceed overseas, but work is proceeding on the Teaching Hospital (for which the Nigerian Government has granted $£ 2,250,000$ ) and soon it is hoped that the final London M.B., B.S., may be taken in Ibadan. At present there are no hospitals in Nigeria suitable to obtain recognition for teaching of the appropriate standards.

Nigeria, with a population estimated at not far short of $30,000,000$, will require far more graduates than the College can at present produce, but the size of the entry is at the moment largely dependent on the production of suitable freshmen by the secondary schools. So far, few suitable candidates have failed to secure entry. An attempt is being made to maintain a proper balance of the different faculties, and copies for the use of readers elsewhere. Many backnumbers of otherwise unobtainable scientific journals are available on microcards ; Ibadan was the first Commonwealth library to use this technique.

Everyone at Ibadan realizes that the future standing of the University College will depend on the quality of the original work carried out there, both by the staff and by visiting investigators using the College's facilities. All departments are planned not only to allow for an increase in student numbers, but also to accommodate visitors from overseas. Several such workers have spent considerable periods at Ibadan. Fulbright Scholars from the United States have, for example, studied primate physiology, poultry husbandry, indigenous songs and other cultural problems. A Medical Research Council team investigated vegetable precursors of cortisone. But the main research must always be done by the College itself, and a good start has been made in all faculties; in medicine, where no clinical teaching will take place for a fow years, research will largely determine the details of the courses which will eventually be given.

At this stage it is impossible to foretell the exact future development of the College. This depends only in part on the College itself. The political situation in Nigeria is changing rapidly, and it is the more

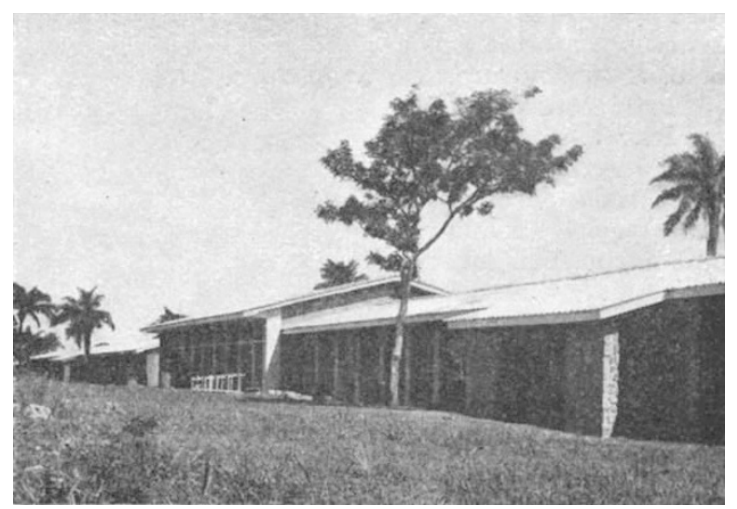

Fig. 3. Elementary chemistry laboratory ; the Department of Chemistry includes three similar parallel buildings 
moderate politicians who speak of "Dominion status in 1956". 'The College is a fully autonomous institution, and so far there have been few attempts, save by the less responsible organs of the popular press, to interfere with this autonomy. Nevertheless, until the College and its standards are firmly established the danger of outside political pressure will remain, and will impose an added strain on those responsible for the well-being of an institution on which the future of Nigeria itself depends so greatly.

\section{INTERNATIONAL FEDERATION FOR DOCUMENTATION}

\section{CONFERENCE IN COPENHAGEN}

$\mathrm{T}$

HE International Federation for Documentation held one of its 'restricted' conferences in Copenhagen during September 28-October 4, which was attended by representatives of some sixteen countries. These conferences consist of a number of meetings of the council and of the active specialist committees of the Federation. Among the committees which met on this occasion were those on universal classification, mechanical selection, technical means of documentation, abstracting, training, and information services. Meetings were also held between members of the staff of the United Nations Educational, Scientific and Cultural Organization and representatives of the council of the International Federation for Documentation, the International Federation of Library Associations and other international bodies concerned with documentation, archives and librarianship. As a step towards closer collaboration, it was agreed that both the International Federation for Documentation and the International Federation of Library Associations should become members of the other's organization and that the next conferences of the two bodies should take place simultaneously in Vienna in 1953. It was also agreed with the representatives of Unesco that a joint consultation committee of international non-governmental organizations in the field of librarianship, documentation and archives be established, and that this committee should arrange the next world conference on these subjects to be held in 1954 or 1955 .

One of the main items discussed by the council of the Federation was the report of its committee on reorganization, which was set up at the end of the conference held in Rome in 1951. This report, which was accepted after minor modification, restated the aims of the Federation in terms suitable for the present; in particular, it made clear that such a body should restrict its activities to those which are truly international in character, leaving studies of a more general nature to its national constituent bodies. Similarly, it was agreed that international technical studies should not necessarily be carried out by the general secretariat but allocated to appropriate national members who would undertake them for the benefit of the Federation as a whole. It also recommended that international specialist bodies should be accepted as members of the Federation in addition to the national co-operating bodies (Aslib in the case of Great Britain). It was recognized that, with the increased amount of research undertaken, especially in the pure and applied sciences, and the consequent volume of publication, special problems of documentation are arising in many scientific and technical fields. As a result, a number of specialist international bodies have already been established, such as the International Council on Building Documentation which was meeting at Copenhagen at the same time as the International Federation for Documentation. The Federation felt itself to be in a position to give advice to international bodies for specialized topics, such as the various international scientific unions, on documentary aspects of their work, and decided to create facilities for such bodies to join the Federation and participate fully in its work.

Among the technical matters agreed as appropriate to the programme of the Federation for 1953, priority was given to the proposals for a guide to centres for microfilm and photocopying services, and centres for international loans and translation services; the production of manuals for instruction in documentation; a directory of the effective members of the Federation, with a description of their activities ; a study of auxiliary publications, including 'unpublished' reports of scientific work; a study of costing and economics in the preparation and sale of photocopies; and a manual of documentary reproduction.

This conference, with its wide scope of technical interest, demonstrated clearly the need for improved services of documentation and information as well as the interest of scientific and technological workers in problems resulting from the mounting pressure of publication. Although a number of international organizations are operative in this and neighbouring fields, the International Federation of Documentation, in encouraging co-operation with other bodies while at the same time improving its own organization and procedures, is showing real leadership and finding a useful continuing function.

\section{ADVISORY COMMITTEE ON ARID ZONE RESEARCH}

\section{MEETING IN LONDON}

$\mathrm{T}$ HE Advisory Committee on Arid Zone Research set up by the United Nations Educational, Scientific and Cultural Organization held its fourth meeting in the Royal Society's rooms, Burlington House, London, during September 29-October 1. Following its former policy, the Committee's recommendations were concerned to a large extent with the dissemination and exchange of information by means of reports and symposia. Reports have already been obtained and circulated on arid zone hydrology, on plant ecology, on the climatic history of arid regions and on the utilization of salt water. A successful symposium on arid zone hydrology organized jointly by Unesco and the Turkish Government was held in Ankara last April. The Committee recommended that qualified experts be commissioned to prepare reports reviewing research on energy sources, including wind and solar energy and their utilization in arid and semi-arid regions, and also on the general characteristics of arid zone soils and their modification. It also recommended that a survey of current research in the field of arid zone plant ecology be prepared. The symposium planned to be held in 1953 will deal with this field of plant ecology in arid regions, and the Committee considered its programme and plans. 